Revista peruana de biología 26(3): 351 - 366 (2019) doi: http://dx.doi.org/10.15381/rpb.v26i3.16779 ISSN-L 1561-0837; elSSN: 1727-9933

Universidad Nacional Mayor de San Marcos

\section{Cladocera (Crustacea, Branchiopoda) of a temporary shallow pond from northern Colombia}

\section{TRABAJOS ORIGINALES}

$\begin{array}{ll}\text { Presentado: } & 04 / 04 / 2019 \\ \text { Aceptado: } & 11 / 08 / 2019 \\ \text { Publicado online: } & 30 / 09 / 2019\end{array}$

Correspondencia:

* Corresponding author

JM. Fuentes-Reinés: Juanfuentesreines@gmail.com

Pedro Eslava: pemo2002@gmail.com

L.M.A. Elmoor-Loureiro: elmoor.loureiro@gmail.com

\section{Cladocera (Crustacea, Branchiopoda) de una charca temporal poco profunda al norte de Colombia}

\author{
Juan M. Fuentes-Reinés* 1,4, Pedro Eslava-Eljaiek², Lourdes M.A. \\ Elmoor-Loureiro ${ }^{3}$
}

1Universidad del Magdalena, Grupo de investigación en Biodiversidad y Ecología Aplicada, Santa Marta, Colombia. AA 731.

2 Universidad del Magdalena, Grupo de investigación en Biodiversidad y Ecología Aplicada, Santa Marta, Colombia. AA 731.

3 Independent researcher.
Otros datos de los autores / biografía: Juan M. Fuentes-Reinés: 0000-0001-5809-4271 Pedro Eslava- Eljaiek: 0000-0002-4779-1589 L.M.A. Elmoor-Loureiro: 0000-0001-7439-9753

4 Doctorado en Ciencia Naturales para el Desarrollo (DOCINADE), Instituto Tecnológico de Costa Rica, Universidad Nacional, Universidad Estatal a Distancia, Costa Rica.

\section{Citación:}

Fuentes-Reinés J.M., P. Eslava-Eljaiek, L.M.A. Elmoor-Loureiro. 2019. Cladocera (Crustacea, Branchiopoda) of a temporary shallow pond from northern Colombia. Revista peruana de biología 26(3): 351 - 366 (Septiembre 2019). doi: http:// dx.doi.org/10.15381/rpb.v26i3.16779

Palabras clave: taxonomía; distribución; charca temporal; micro-crustáceo de agua dulce; La Guajira.

Keywords: taxonomy; distribution; temporal pond; freshwater micro-crustaceans; La Guajira.

\begin{abstract}
Eighteen species of cladocerans are recorded from a temporary pond in northern Colombia; 12 of these records are new for La Guajira Department: Diaphanosoma brevireme Sars, 1901, D. dentatum Herbst, 1968, Sarsilotona serricauda (Sars, 1901), Moina micrura micrura Kurz, 1874, M. reticulata Daday, 1905, Grimaldina freyi Neretina and Kotov, 2017, Kurzia polyspina Hudec, 2000, Leydigia cf striata Birabén, 1939, Ovalona cf glabra (Sars, 1905), Chydorus nitidulus (Sars, 1901), Dunhevedia crassa King, 1853 and Pseudosida sp.; this latter taxon could be an yet undescribed species. The cladoceran fauna from the surveyed area is represented mostly by widespread species and commonly found in the Neotropical regions, but local morphological data are scarce in the regional literature. Brief diagnostic descriptions of the species recorded for the Colombian cladoceran fauna are provided together with illustrations of taxonomically significant appendages, morphological remarks, notes on the variability of some species, and their distribution.

\section{Resumen}

Dieciocho especies de cladóceros son registrados de una charca temporal al norte de Colombia; 12 de estos registros son nuevos para el departamento de la Guajira: Diaphanosoma brevireme Sars, 1901, D. dentatum Herbst, 1968, Sarsilotona serricauda (Sars, 1901), Moina micrura micrura Kurz, 1874, M. reticulata Daday, 1905, Grimaldina freyi Neretina and Kotov, 2017, Kurzia polyspina Hudec, 2000, Leydigia cf striata Birabén, 1939, Ovalona cf glabra (Sars, 1905), Chydorus nitidulus (Sars, 1901), Dunhevedia crassa King, 1853 y Pseudosida sp; este último taxón podría ser un especie todavía no descrita para la ciencia. La fauna de cladóceros del área estudiada está principalmente representada por especies de amplia distribución y comúnmente encontradas en la región Neotropical, pero la información local morfológica de estas especies reportadas son escasas en la literatura regional. Se proporcionan breves descripciones diagnosticas de las especies registradas para la fauna de cladóceros colombianos, juntos con ilustraciones de apéndices taxonómicamente importantes, comentarios morfológicos, notas de variabilidad de algunas especies y su distribución.
\end{abstract}




\section{Introduction}

Semi-arid climate characterizes the north of Colombia; nevertheless, the rains in this zone can form temporary shallow ponds that can house a variety of organisms. These small aquatic ecosystems have largely been neglected, and most of them are totally unknown in its invertebrate biodiversity. Cladocerans group are invertebrates essential as components of the food chain, playing an important role in the trophic webs, transferring energy from the primary producers (e.g. phytoplankton, Periphyton) until secondary consumers (e.g. fish, macroinvertebrate larvae) (Melão et al. 2005).

In Colombia, the knowledge about the cladoceran fauna has been increased in recent years considerably (Fuentes-Reinés \& Elmoor-Loureiro 2015a, 2015b, 2011, Fuentes-Reinés et al. 2012, Fuentes-Reinés \& Zoppi de Roa 2013, Fuentes-Reinés 2014a, 2014b, 2014c, 2015, Kotov \& Fuentes-Reinés 2014, 2015a, 2015b, Sinev \& Fuentes-Reinés 2016, Fuentes-Reinés et al. 2018). According to Fuentes-Reinés et al. (2018), there are 107 valid species in Colombia, being the Caribbean region the one with the largest number of recorded species (72 spp.).

Taxonomic studies on cladoceran fauna in the La Guajira Department are scarce (Fuentes-Reinés 2014a). This study is aimed to investigate the cladoceran fauna in a temporary pond from northern Colombia, provide descriptions and appropriate illustrations of some remarkable taxa, and improve the knowledge on the distribution of some cladoceran species in Colombia and the Neotropical region.

\section{Material and methods}

Biological samples were collected from a small temporary pond, Maicao-La Guajira, Colombia, (11 ${ }^{\circ} 23^{\prime} 04.63^{\prime \prime N}$, $\left.72^{\circ} 16^{\prime} 31.10^{\prime \prime W}\right)$. Qualitative surveys were realized during October and November 2018 and January and February 2019. The surveyed area was dominated by Prosopis juliflora (Trupillo) and Caesalpinia coriaria Divi-Divi), which are some typical plants of the zone. Cladocerans were most numerous in habitats associated with the roots of plants. The water temperature during sampling was $31.8^{\circ} \mathrm{C}$, conductivity $1464 \mu \mathrm{S} / \mathrm{cm}$ values, $\mathrm{pH} 7.99$ and dissolved oxygen $3.97 \mathrm{mg} / \mathrm{L}$. (average of the values observed in two sampling periods), and they were measured with a multiparameter WTW 350i.

Sixteen samples were collected using 25 L bucket, vertically hauled among vegetation and open water, after it was filtered with a $45 \mu \mathrm{m}$ mesh size plankton net to obtain concentrates of $100 \mathrm{ml}$ that were immediately preserved in $70 \%$ alcohol. Three samples were stained with Bengal Rose, and the cladocerans were sorted out and embedded in toto within a drop of a glycerol-formaldehyde mixture for its dissection. Images acquiring were performed with a Kodak Easy Share C140 digital camera attached to a microscope. Individuals were measured in lateral position, from the anterior end of the rostral area to the posterior margin of the valve, using an ocular micrometer. Identifications were according to Korovchinsky (1992), Elmoor-Loureiro (1997), Hudec (2000), Smir- nov (1996), Fuentes-Reinés and Zoppi de Roa (2013) and Fuentes-Reinés et al. (2012). Voucher specimens were deposited at the Centro de Colecciones Biológicas de la Universidad del Magdalena, Colombia (CBUMAG).

\section{Results}

Eighteen cladocerans species were identified in temporary ponds in the course of this study. Of these species, twelve are new records for La Guajira Department. They belong to five families and eleven genera (Table 1). Chydoridae showed the highest species richness (6), followed by Sididae (5), Moinidae (3), Macrothricidae (3) and Daphniidae (1). Brief remarks and descriptions, with illustrations, for the relevant species, are given below.

\section{FAMILY SIDIDAE BAIRD, 1850 \\ GENUS DIAPHANOSOMA FISCHER, 1850}

\section{Diaphanosoma brevireme Sars, 1901}

Synonymy: Diaphanosoma neotropicum Brehm and Thomsen, 1936; D. sarsi Van de Velde et al. 1978 in Fuentes-Reinés et al. (2012).

Material examined: 3 adult females, catalog number: CBUMAG: MEI: 0014

Remarks: In our pond, it was the least abundant species among the genus Diaphanosoma and was collected in January. The specimen examined bears the diagnostic features of $D$. brevireme as described by Korovchinsky (1992), Fuentes-Reinés et al. (2012), and Fuentes-Reinés and Elmoor-Loureiro (2015b). Habitus robust with roundish-oval head as in Figure 1A. This species can be easily separated from its congeners by a combination of the following characteristics that are present in our specimens: (1) folded ventral margin, (2) denticles on postero-ventral valve margin which decrease proximally (Fig. 1B). Body length is between 644 - $672 \mu \mathrm{m}(\mathrm{n}=3)$. In Colombia, this species only has been reported in the Caribbean and Andean region (Kotov \& Fuentes-Reinés, 2015b).

\section{Diaphanosoma spinulosum Herbst, 1975}

Material examined 35 adult females, catalog number: CBUMAG: MEI: 0015

Remarks: It was the most abundant species among the genus Diaphanosoma in the studied pond and was collected in all samplings. The specimens share the diagnostic features from specimens of D. spinulosum previously reported from the adjacent Guajira Department in Colombia (Fuentes-Reinés 2014c). Habitus robust with rectangular head (Fig. 1C). In the Neotropics, D. spinulosum can be separated from its congeners by the folded ventral margin and denticles on postero-ventral valve margin which decrease distally and between large denticles bear small denticles interspersed (Fig. 1D). Body length is between $770-798 \mu \mathrm{m}(\mathrm{n}=35)$. In Colombia, it is found in the Andean, Amazon and Caribbean regions (Kotov \& Fuentes-Reinés 2015b) 


\section{Diaphanosoma dentatum Herbst, 1968}

Material examined: 10 adult females, catalog number: CBUMAG: MEI:0016

Remarks: The female specimens examined were assignable to $D$. dentatum following the diagnostic characters presented by Korovchinsky (1992) and Elmoor-Loureiro (1997). Habitus robust with head cone shaped (Fig. $1 \mathrm{E})$. In the neotropics, this species can be distinguished by bearing small denticles decreasing distally on posteroventral valve margin (Fig. $1 \mathrm{~F}$ ). Body length is between $1022-1050 \mu \mathrm{m}(\mathrm{n}=4)$. It was found in October and November. In Colombia, it has been reported from the Andean and Caribbean regions (Kotov \& Fuentes-Reinés 2015b).

\section{GENUS SARSILOTONA KOROVCHINSKY, 1985}

\section{Sarsilotona serricauda (Sars, 1901)}

Synonymy: Laptonosis fasciculata Daday, 1905; Birge, 1910; Sarsilatona serricauda, Korovchinsky, 1985. In Fuentes-Reinés et al. (2012):125.

Material examined: 3 adult females, catalog number: CBUMAG: MEI: 0017

Remarks: It was collected in November. Habitus robust (Fig. 2A), antenna I large (Fig. 2B) with sensory papillae and long spinulose seta on the end of the basal part. In the Neotropics, $S$. serricauda can be confused with $S$. behningi; nevertheless they can be separated by: (1) two unequal spines on distal of the first segment of upper 2 segmented antennal branch in $S$. serricauda (Fig. 2C, Korovchinsky 1992, fig. 94; Fuentes-Reinés et al. 2012 fig. 4B) whereas they are almost equal in length in S. behningi (Korovchinsky 1992, fig. 108); (2) dorsal prominence of postabdomen very large and pointed in $S$. serricauda (Fig. 2D, Korovchinsky 1992, fig 101, FuentesReinés et al. 2012, fig. 4D) whereas in S. behningi dorsal prominence of postabdomen are small and round (Korovchinsky 1992, fig. 104). In the examined specimens from La Guajira, the spinules on the long sensory seta of antenna I is very short (Fig. 2B) but they are long in the specimens reported by Korovchinsky (1992, fig. 92) from Itatiba-Brazil. This character appears to be variable in the species. Body length is between $700-728 \mu \mathrm{m}(\mathrm{n}=$ 3). In Colombia, it is distributed in the Andean and Caribbean regions (Kotov \& Fuentes-Reinés 2015b).

\section{GENUS PSEUDOSIDA HERRICK, 1884}

\section{Pseudosida sp.}

Remarks. This genus has been only hitherto reported in the Neotropical, Nearctic, Australasian, Oriental regions, and is represented by four species: $P$. ramosa (Daday, 1904), P. bidentata Herrick, 1884, P. australien-

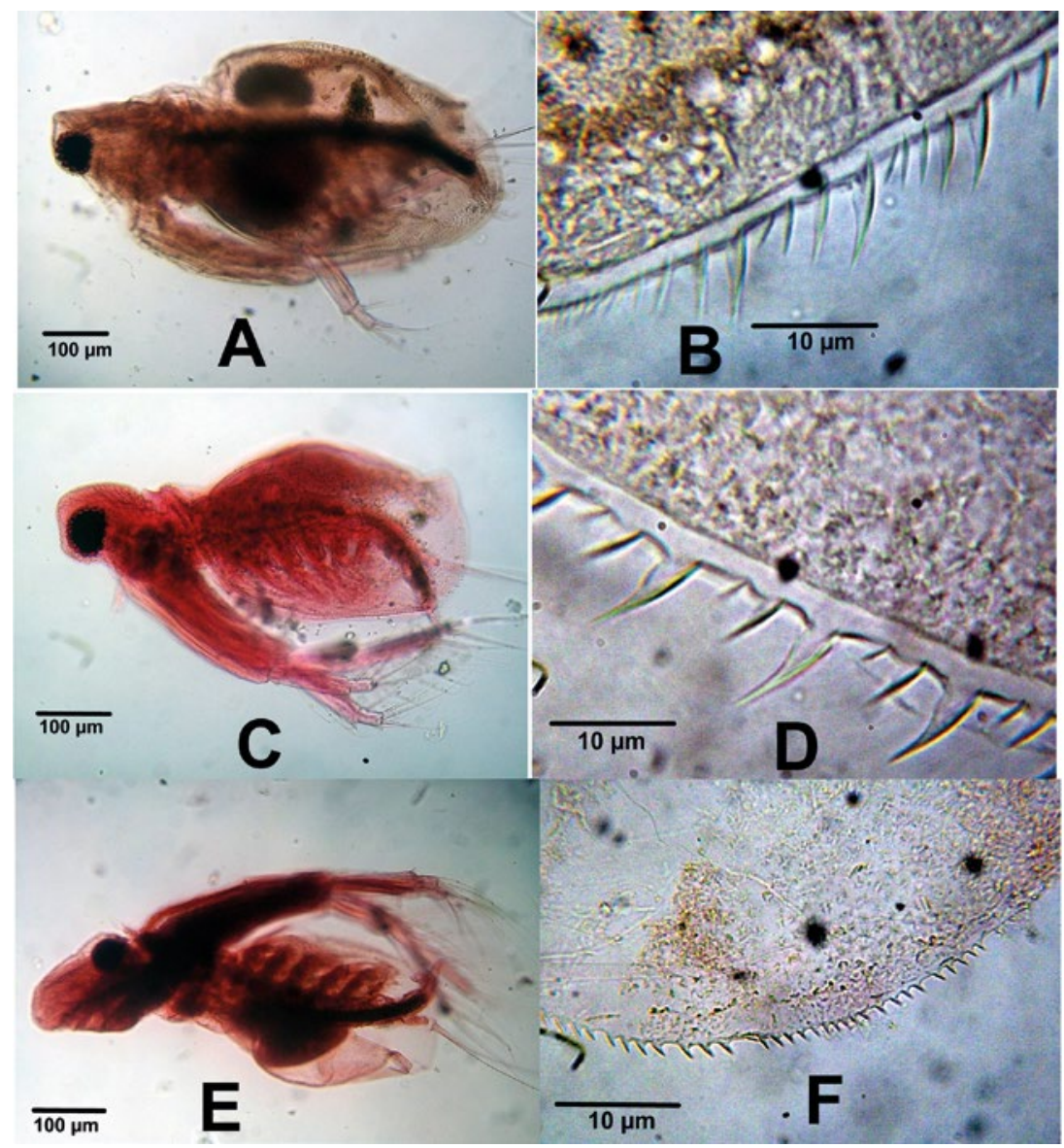

Figure 1. Cladocerans from a temporary pond, La Guajira. A-B Diaphanosoma brevireme. A. Habitus. B. Postero-ventral valve margin. C-D. Diaphanosoma spinulosum, C. Habitus. D. Postero-ventral valve margin. E-F. Diaphanosoma dentatum. E. Habitus. F. Posteroventral valve margin. 
sis Korovchinsky, 1983 and P. szalayi (Daday, 1898). The two former have been recorded in the Neotropics (Korovchinsky, 1992, Fuentes et al. 2012, Kotov \& FuentesReinés, 2015b). Pseudosida sp. was found in open water in October and November. A preliminary analysis of our specimens show morphological features which indicates that it could probably represent an undescribed species. This genus requires revision.

\section{FAMILY DAPHNIIDAE STRAUS, 1820 GENUS CERIODAPNIA DANA, 1853}

\section{Ceriodaphnia cornuta Sars, 1885}

Synonymy: C. cornigera Jiang Xiezhi, 1977; C. cornuta, Montú and Gloeden, 1986; Elmoor-Loureiro, 1998 in Fuentes-Reinés et al. (2012):128

Material examined: 16 adult females, catalog number: CBUMAG: MEI: 0019

Remarks: Habitus as Figure 2E. It was formerly described from Australia (Sars 1885) and has been recorded in a global scale in the tropics and subtropics (ElíasGutiérrez et al. 2006). This species can be presented in two variant forms: (1) with cephalic projection (Fig. 2F),
(2) without cephalic projection. In Colombia, both forms has been recorded (Fuentes-Reinés \& Elmoor-Loureiro 2015a). Ceriodaphnia cornuta is considered a species complex and its diversity is underestimated (Sharma \& Kotov 2013). Hitherto, only two molecular studies have been carried out. The first applied molecular study was in Mexico and Guatemala (Elías-Gutierrez et al. 2008) and the second one was in Australia, showing strong continental endemism (Sharma \& Kotov 2013). Body length is between $392-420 \mu \mathrm{m}(\mathrm{n}=16)$. It was collected in all the sampled period. In Colombia, it occurs in the Amazon, Andean and Caribbean regions

\section{FAMILY MOINIDAE GOULDEN, 1968 GENUS MOINODAPNIA HERRICK, 1887}

\section{Moinodaphnia macleayi (King, 1853)}

Synonymy: Moina macleayi King, 1853; Moina submucronata Brady, 1886; Moinodaphnia alabamensis Herrick, 1887; Moinodaphnia mocquerysi Richard, 1892; Moinodaphnia macleayi Brehm, 1953 in Fuentes-Reinés et al. (2012).136

Material examined: 25 adult females, catalog number: CBUMAG: MEI: 0020
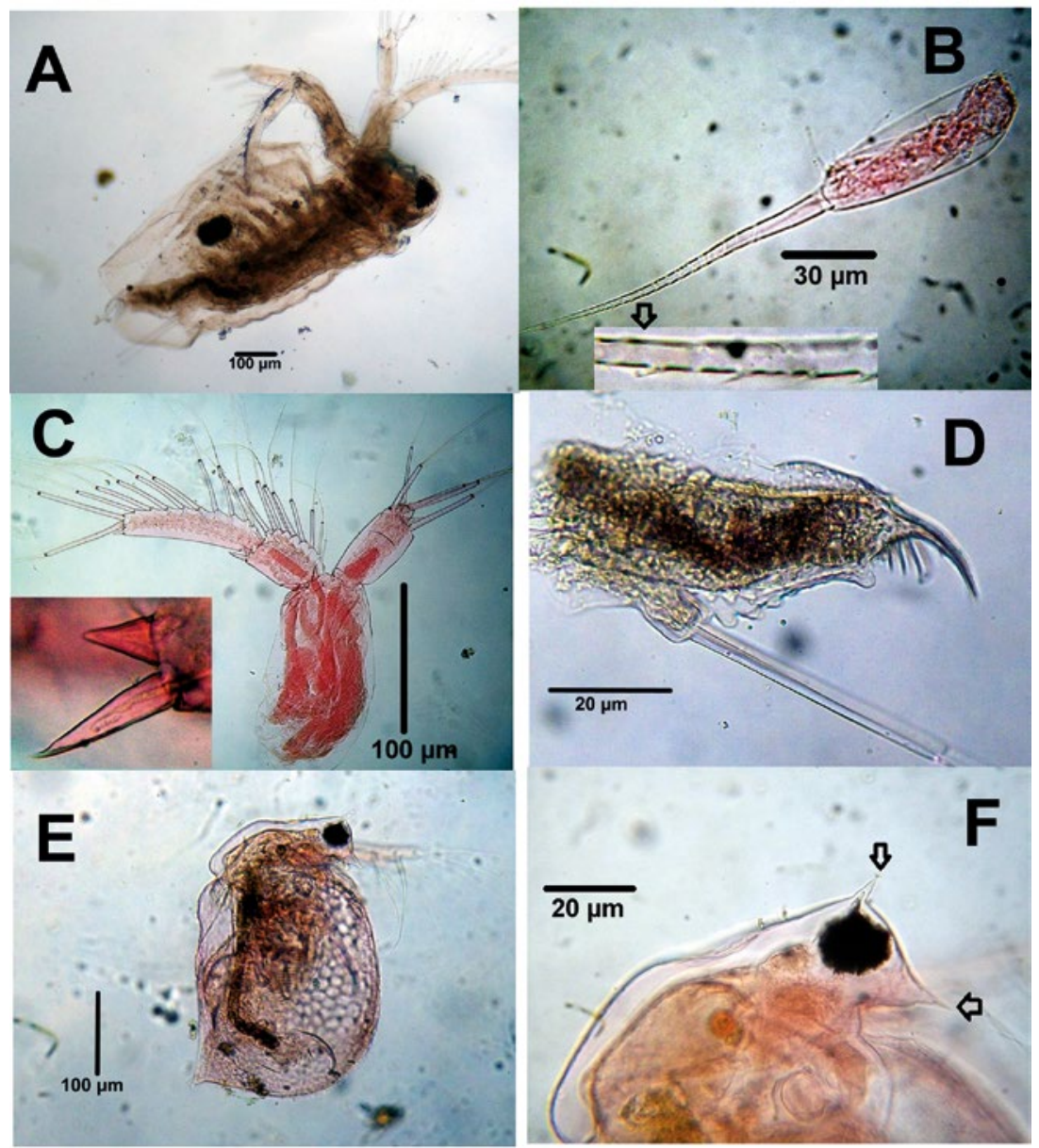

Figure 2. Cladocerans from a temporary pond, La Guajira. A-C. Sarsilotona serricauda, A. Habitus. B. Antenna I (The arrow points at the spinules on long sensory seta). C. Antenna II. D. Postabdomen. E-F. Ceriodaphnia cornuta, E. Habitus. B. Rostrum (The arrows point at the cephalic projections). 
Remarks: This species was collected between macrophytes during November. This is the only known species within genus Moinodapnia and can be recognized by bearing four setae on terminal segment of exopod of second antenna. Body length is between $840-868 \mu \mathrm{m}$ $(n=25)$. In Colombia, this species has been reported from the Andean, Amazon and Caribbean regions (Kotov \& Fuentes-Reinés 2015b). The genus needs to be revised worldwide.

\section{GENUS MOINA BAIRD, 1850}

\section{Moina micrura micrura Kurz, 1874}

Synonymy. Moina propinqua Sars, 1885; Moina weberi Richard, 1891; Moina dubia De Guerne \& Richard, 1892; Moina paradoxa Stingelin, 1900; Moina ciliata Daday, 1905; Moina makrophthalma Stingelin, 1913; Moina weismanni Tsi Chung \& Clement, 1954; Moina micrura Srámek-Husek, Straskraba \& Brtek, 1962; Goulden, 1968, in Fuentes-Reinés et al. (2012):136

Material examined: 50 adult females, catalog number: CBUMAG: MEI: 0021

Remarks: It was the most abundant and frequent species among genus Moina and was collected in all sam- plings. Habitus as figure 3A, the postabdomial claw with an unequal bident tooth (Fig. 3B). Limb I with an anterior seta on the penultimate segment (Fig. 3C). The male habitus as figure 3D and can be distinguished from female by: 1) the long antenna (Fig. 3D); 2) IDL with a strong long curved hook and two elements (Figs. 3E-F). Body length is between $910-938 \mu \mathrm{m}(\mathrm{n}=10)$.

According to Elías-Gutierrez (2019), Moina micrura from American continent are a complex of species, formed at least by five distinct lineages and require further detailed studies. In Colombia, it is distributed in the Andean, Amazon and Caribbean regions (Kotov \& FuentesReinés 2015b). The genus needs to be revised worldwide

\section{Moina reticulata Daday, 1905}

Material examined: 2 adult females, catalog number: CBUMAG: MEI: 0022

Remarks: It was collected in October in open water. This species was originally described by Daday 1905 and has been reported in Neotropical and Afrotropical regions (Daday 1905, Lamoot \& Dumont 1974). Nevertheless, the population from the latter region could probably be an undescribed species (Kotov \& Fuentes-Reinés
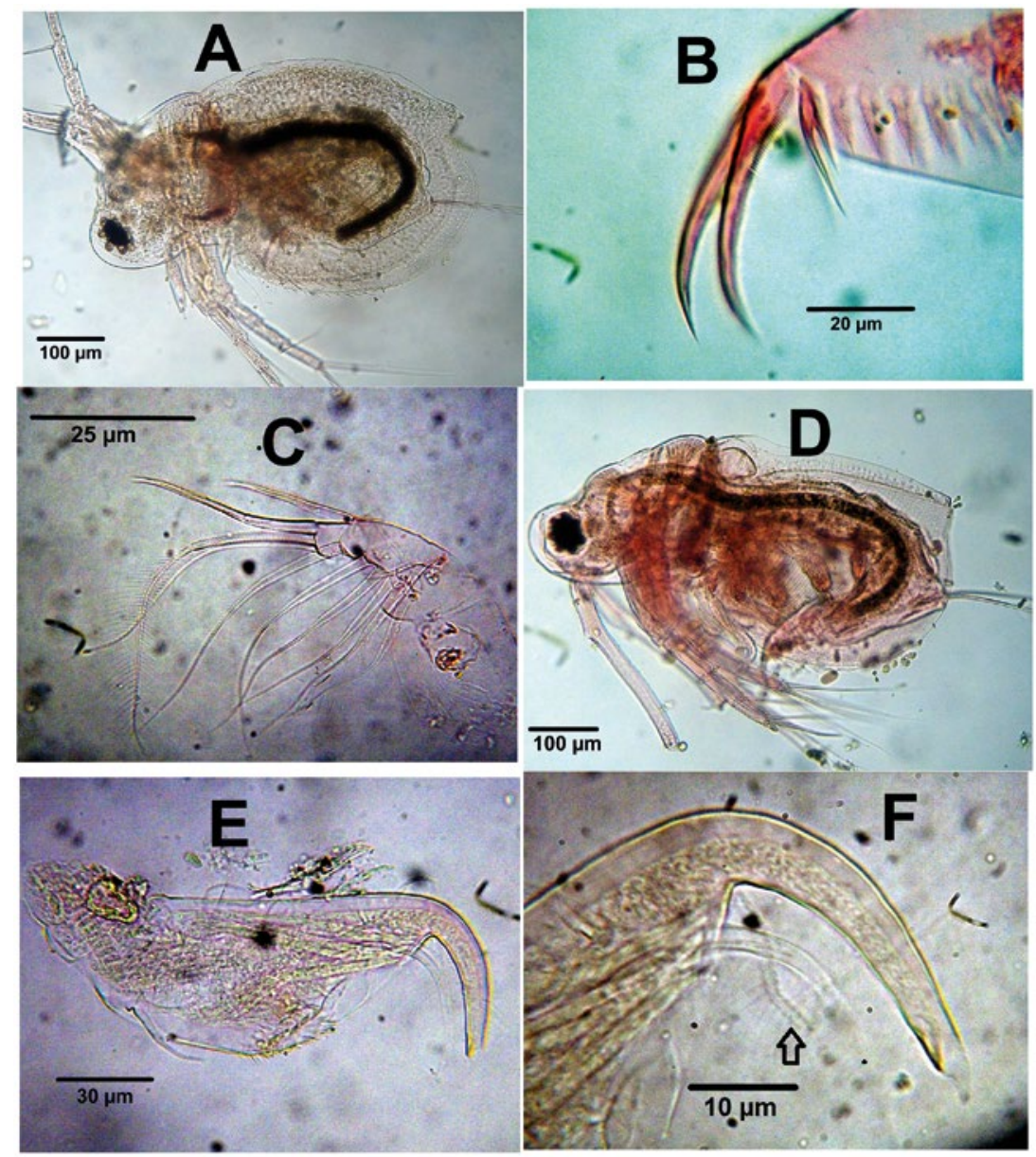

Figure 3. Cladocerans from a temporary pond, La Guajira. Moina micrura micrura. A. Habitus. B. Postabdominal claw. C. trunk limb I. D-F. Male. D. Habitus. E. Trunk limb I. F. copulatory hook (The arrow points at setulose seta). 
2015b). Body length is between $560-588 \mu \mathrm{m}(\mathrm{n}=2)$. In Colombia, it occurs in the Amazon and Caribbean regions.

\section{FAMILY MACROTHRICIDAE, NORMAN \& BRADY, 1867 GENUS MACROTHRIX BAIRD, 1843}

\section{Macrothrix elegans Sars, 1901}

Material examined: 4 adult females, catalog number: CBUMAG: MEI: 0023

Remarks: Macrothrix elegans is one of the most common Macrothrix species in the Neotropical region (Kotov et al. 2004), and is considered a phytophylous species (Sousa \& Elmoor-Loureiro 2008). It was collected in November among macrophytes and was less abundant amid the observed Macrothrix. The body is ovoid (Fig. 4A). In the Neotropics, M. elegans can be differentiated from its congeners by: (1) antenna I straight to slightly curved with $7-9$ short transverse rows of denticles on anterior surface (Fig. 4B), (2) valve with striae (Fig. 4C), (3) postabdomen bi-lobed and narrowed distally with slightly robust denticles on preanal margin (Fig. 4E), (4) swimming seta without proximal setules (Fig. 4F).

In terms of the well-known intraspecific variability of the species (Kotov et al. 2004), specimens from La Guajira are identical in most aspects to those reported in
Brazil. However, they showed a subtle difference in the setae on the IDL of limb I which were more curved and stronger in La Guajira population (Fig. 4D) than in Brazilian specimens described by Kotov et al. (2004, fig. 91). Body length $588-658(n=4)$. In Colombia, it occurs in the Caribbean region (Kotov \& Fuentes-Reinés, 2015b).

\section{Macrothrix spinosa King, 1853}

Synonymy: Macrothrix goeldi Richard, 1897; $M a-$ crothrix squamosa Sars, 1901; Macrothrix affinis Brady, 1904 in Fuentes-Reinés et al. (2012): 130

Material examined: 8 adult females, catalog number: CBUMAG: MEI: 0024

Remarks: In our samples, it was the most abundant species among Macrothrix. In Colombia, this species only has been reported in the Caribbean region (Kotov \& Fuentes-Reinés, 2015b). This species need to be revised. Body length is between $336-364 \mu \mathrm{m}(\mathrm{n}=8)$. In our study it was collected in October and November

GENUS GRIMALDINA RICHARD, 1892

\section{Grimaldina freyi Neretina and Kotov, 2017}

Synonymy: Grimaldina brazzai Richard in Sars 1901:

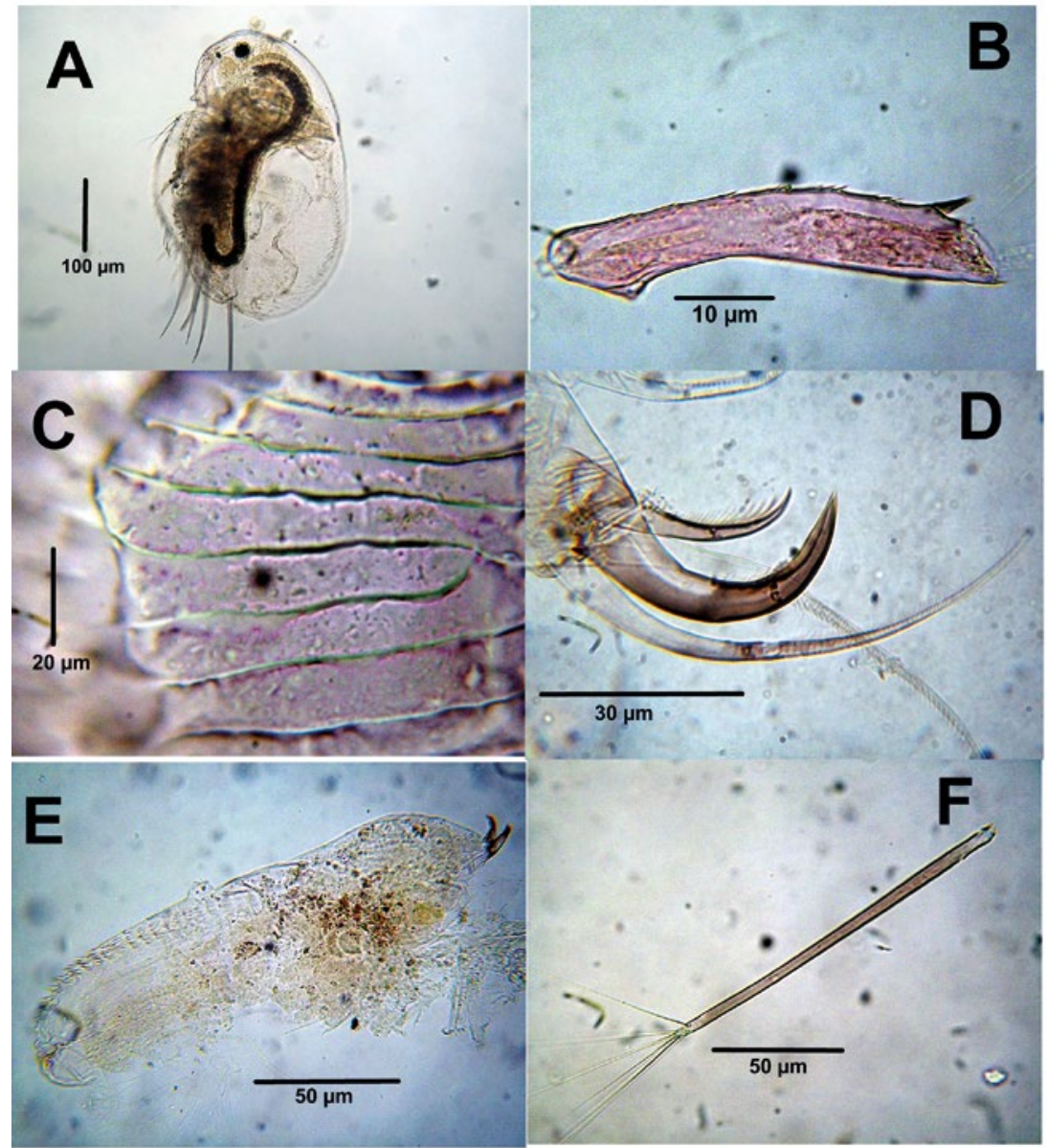

Figure 4. Cladocerans from a temporary pond, La Guajira. Macrothrix elegans. A. Habitus. B. Antenna I. C. valve. D. Trunk limb I. E. Postabdomen. F. Swimming seta. 
p. 28-31, pl. 5: figs. 1-14; Hollwedel et al. 2003: p. 78, figs. 10-40. ? Grimaldina brazzai Richard in Kořínek 1984: pl. XXVI, fig. 1; Silva-Briano 1998: p. 151, figs. 9, 10; Garfias-Espejo \& Elías-Gutiérrez, 2003: p. 108, figs. 1-8; Elías-Gutiérrez et al. 2006: p. 12-13, figs. 21-31; Fuentes-Reinés et al. 2012: fig. 12 a-d. In Neretina \& Kotov (2017):307

Material examined: 4 adult females, and 1 adult male catalog number: CBUMAG: MEI: 0025, CBUMAG: MEI:0030

Remarks: It was found among vegetation in February. Female habitus as in Figure 5A, antenna I tubular with a row of spinulae along posterior margin, decreasing distally (Fig. 5B), antenna II (Fig. 5C) with setal formula 0-1$1-3 / 0-1-3$, the largest seta of proximal endopod segment armed by short stiff setulae on proximal and distal portions (Figs. 5C-D), basal segment bearing a small spine and bisegmented seta (Fig. 5E). Postabdomen large and semircular, divided in two lobes (Fig. 5F). ODL and IDL of trunk limb I with one and three setae respectively (Fig. $6 \mathrm{~A}$ ), trunks limb II-V undistinguishable from description of Neretina \& Kotov, 2017, the latter one (Fig. 6B) with round and ovoid preepiodite and epipodite respectively, the outer exopod with a setulated seta reaching beyond the preepipodite (Fig. 6B), the inner portion of exopod with two subequal setae, the proximal one is about 2 times longer than the distal one (Fig. 6C).

Male habitus as in female but smaller (Fig. 6D), antenna I as in female but with rows of spinulae in both anterior and posterior margin (arrowed in Fig. 6E). Antenna II as in female (see Neretina \& Kotov 2017, fig 11B, present data, Fig. 5E). Trunk of Limb I with a strong curved copulatory hook (Fig. 6F). ODL very large with one seta, IDL with 3 setae subequal size, trunk limb V as in female. Body length of female is between $700-714 \mu \mathrm{m}$, and male is $546 \mu \mathrm{m}$

This genus is composed by two species: G. brazzai Richard, 1892 and $G$. freyi, which are superficially similar; nevertheless they can be separated by: (1) the distance between bases of spinules on endopod segment of antenna II are almost two times longer than diameter of the seta in G. freyi (Figs. 5C-D, Neretina \& Kotov 2017, figs. 11C-D) whereas in G. brazzai the distance is about four

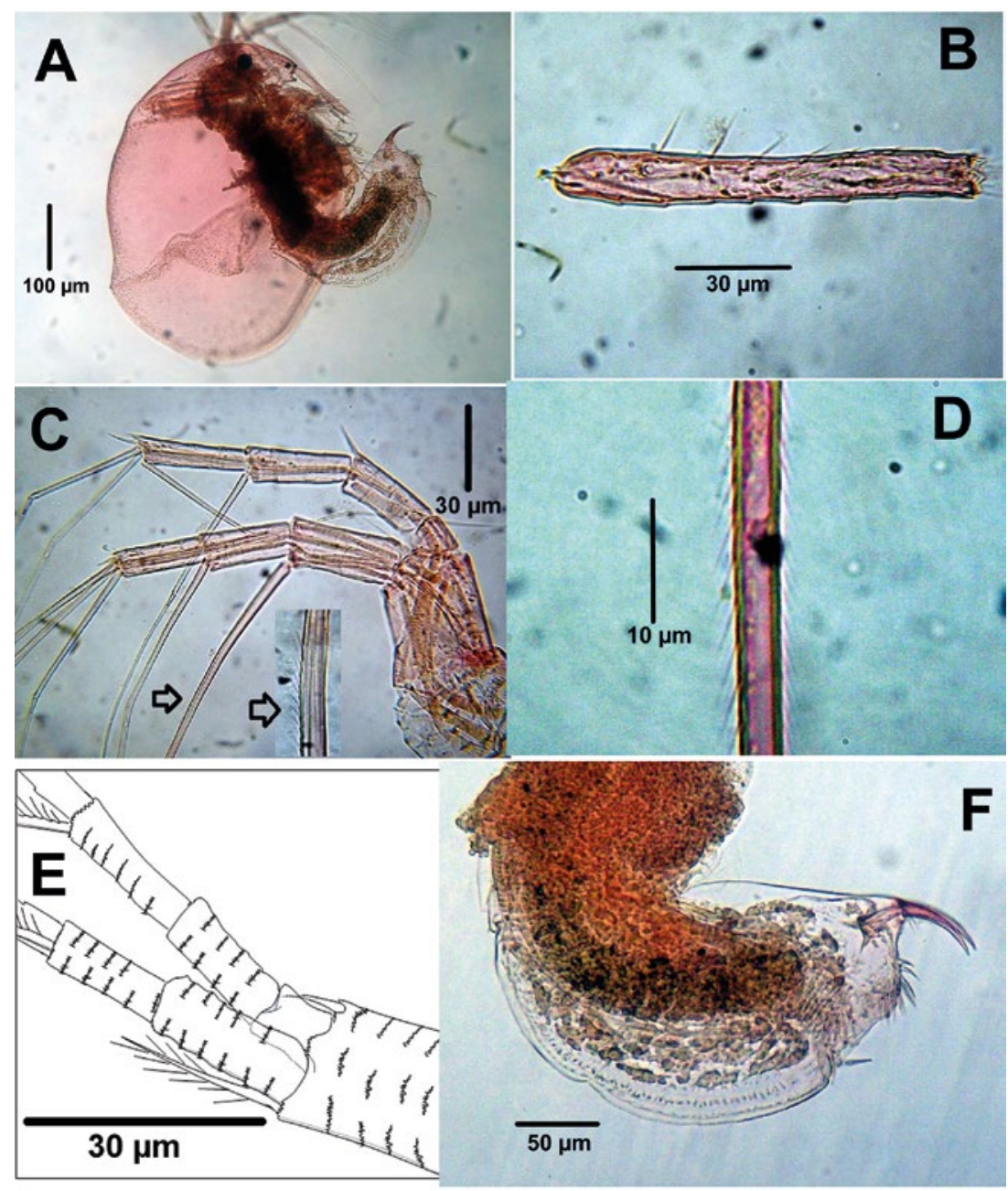

Figure 5. Cladocerans from a temporary pond, La Guajira. A. Grimaldina freyi A. Habitus. B. Antenna I. C. Antenna II (arrows point at short stiff setulae on proximal endopodal segment). D. Short stiff setulae on proximal endopodal segment of A2. E. Postabdomen. F. Trunk limb I. 
times (Neretina \& Kotov 2017 figs 4C-D); (2) the ratio of seta 2/seta 3 length on the inner distal portion of exopod of the fifth thoracic limb is about 2 in G. freyi (Fig. 6C, Neretina \& Kotov 2017 figs. 13D-E) vs. 4 in G. brazzai (Neretina \& Kotov 2017, figs 6D-E), (3) the setullated seta on outer exopod of trunk limb $\mathrm{V}$ goes beyond the preepipodte in G. freyi (Fig. 6B, Neretina \& Kotov 2017, fig 13C) whereas in G. brazzai the setullated seta reaches the half of preepipodite (Neretina \& Kotov 2017, fig 6C); (4) the basal segment of antenna II of $G$. freyi male bears one long seta (Fig. 5E) vs. 3 setae in G. brazzai (Kořínek 1984, plate XXVI, fig 6); (5) the IDL of trunk limb I of $G$. freyi male bear 3 setae vs. 1 seta in $G$. brazzai (Kořínek 1984, plate XXVI, fig. 3) nevertheless this structure could have been overlooked by Kořínek (1984) and more specimens should be analyzed.

In term of intraspecific variability, the antenna II of the male of $G$. freyi from Colombia was observed to bear a row of spinulae on posterior and anterior margin (Fig. $6 \mathrm{E})$ vs. one row on posterior margin in population from Brazil (Sars 1901, fig 13), it is possible this row of spinules could be overlooked by the author.

FAMILY CHYDORIDAE DYBOWSKI \& GROCHOWSKI, 1894 EMEND. FREY, 1967 GENUS KURZIA DYBOWSKI \& GROCHOWSKI, 1894

\section{Kurzia polyspina Hudec, 2000}

Material examined: 5 adult females, catalog number: CBUMAG: MEI:0026

Remarks: It was found among macrophytes in January and February, habitus as in Figure 7A. Labrum triangular (Fig. 7B), three connected head pores (Fig. 7C). In Colombia this species can be confused with $K$. cf media nevertheless they can be separated by: (1) distal corner of postabdomen forming a lobe not protruding beyond terminal claw base with three thick denticles in $K$. cf media (Hudec 2000, fig 13, Fuentes-Reinés et al. 2012 , fig. 21B) while in K. polyspina the postabdominal distal corner does not form lobe and bears one denticle (Fig. 7D, Hudec 2000,fig. 19, Fuentes-Reinés et al. 2012, fig. 20D ), (2) the two longest IDL setae bear different spicules $(2+1)$ in K. polyspina (Fig. 7D, Hudec 2000, fig 21; Fuentes-Reinés et al. 2012, fig 20C) whereas in $K$. cf media they are uniform and fine (Hudec 2000, FuentesReinés et al. 2012, fig 21D). In Colombia, this specimen occurs in the Caribbean region (Kotov \& Fuentes 2015b). Body length of female is between 490-518 $\mu \mathrm{m}$

GENUS LEYDIGIA KURZ, 1875

\section{Leydigia cf. striata Birabén, 1939}

Material examined: fifty adult females, 5 adult males catalog number:CBUMAG: MEI: 0027, CBUMAG:MEI:0029-1,CBUMAG:MEI:0029-2

Remarks: It was found among macrophytes in all samplings and was the most abundant observed species among the family Chydoridae. The morphology of the fifty adult female specimens from La Guajira, Colombia agrees in general with previous descriptions and illustrations of the species (Kotov et al. 2003, Kotov \& Elías-Gutierrez 2004, Kotov 2009, Fuentes-Reinés 2014b, Fuentes-Reinés \& Elmoor-Loureiro 2015a). Leydigia cf striata can be recognized from its congeners by a unique combination of characters including: (1) The female postabdomen is the narrowest among its congeners of acanthocercoidesgroup; (2) setules in lateral fascicules on labrum are shorter or the same size as marginal setae; (3) preanal margin of female postabdomen with hillokcs, (4) basal segment of the distal most scrapper of Limb II (setulated). These distinctive traits are also present in La Guajira specimens examined, thus its identity can be herein confirmed.

The male habitus as Figure 7F. Rostrum short, antenna I reaching the tip of the rostrum with thick male seta and slender antennular sensory seta about $1 / 4$ of length from distal end (Figs. 7F, 8A). Labral keel triangularovoid, setulles in lateral fascicules shorter or the same size as marginal setae (arrowed in Fig. 8B). Three major head pores of equal size (Fig. 8C), distance from posterior pore to posterior margin of head shield (PP) about 1.8 - 2.0 distance between anterior and posterior pores (IP). Lateral head pores minute, located about 0.09 IP from midline, at the level of anterior major head pore. Trunk of Limb I with large, U-shaped copulatory hook with tiny spines on the marginal end (Figs. 8E-F), very difficult to observe. ODL very large, IDL with four setae of subequal size: one male seta, two large and one-minute setae (Figs. 8E-F). Postabdomen narrower than female (Figs. 9B-C), with maximum height in the middle, height/ length ratio $=2.26-2.46$. Preanal margin with $2-4$ hillocks (Fig. 9D). Numerous fascicules $(14-16)$ of lateral setules on proximal half of postanal and anal margin (Fig. 9C), postabdominal claw slender than female, basal spine present (Fig. 9E) or absent. Penis relative thick, shorter than claw with a stylet at its tip (Fig. 9F).

Hitherto only one male specimen has been reported from Lake Titicaca (Harding 1955, Kotov et al. 2003; Kotov 2009) and some subtle difference can be observed in our specimens: (1) preanal margin of postabdomen with hillocks in Colombia population (Fig. 9D ) while it is absent in specimen from Lake Titicaca (Kotov et al. 2003, fig 96; Kotov 2009, fig 381), (2) IDL with 3 long subequal and one minute setae (Figs. 8E-F ) vs. 3 setae (Kotov et al. 2003, fig. 99; Kotov 2009, pag. 74); (3) with three tiny spinule on the margin end of copulatory hook in Colombia population (Figs. 8E-F), wich were not mentioned in the description of the specimen from Titicaca Lake (Kotov et al. 2003). It is possible that this character was overlooked. Body length of male is between $588-658 \mu \mathrm{m}(\mathrm{n}=5)$

Variability: one male was observed to bear four long setae, instead three long and one minute setae (Fig. 9A). Another male was observed to bear the minute spine on the base of postabdominal claw.

\section{Ovalona cf. glabra (Sars, 1901)}

Material examined: 2 adult females, catalog number: CBUMAG: MEI: 0028 


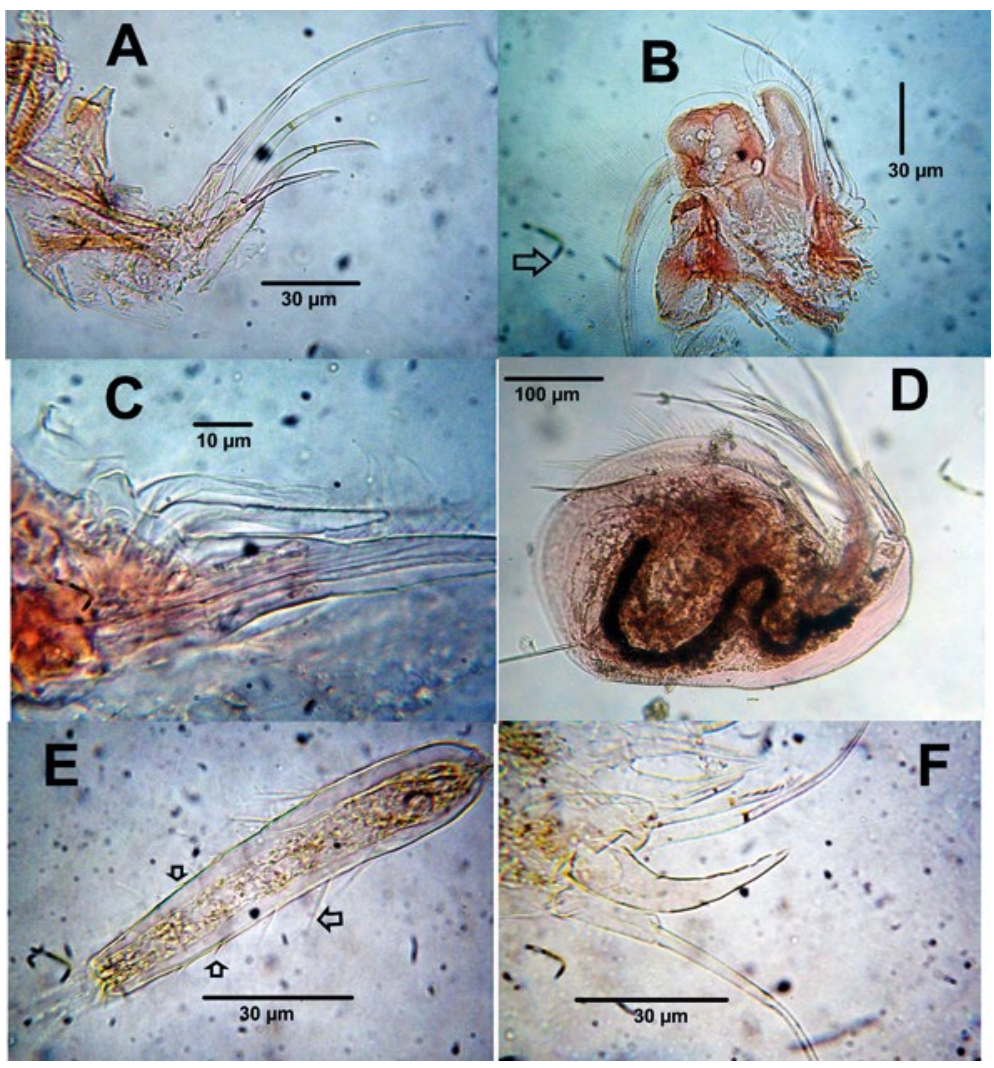

Figure 6. Cladocerans from a temporary pond, La Guajira. A-C. Grimaldina freyi female. A. Trunk limb I. B. Trunk limb V (The arrow points at the seta on the outer exopod), C. Idem, inner portion of exopod. D-F. Male. D. Habitus. E. Antenna II. F. IDL of trunk limb I.

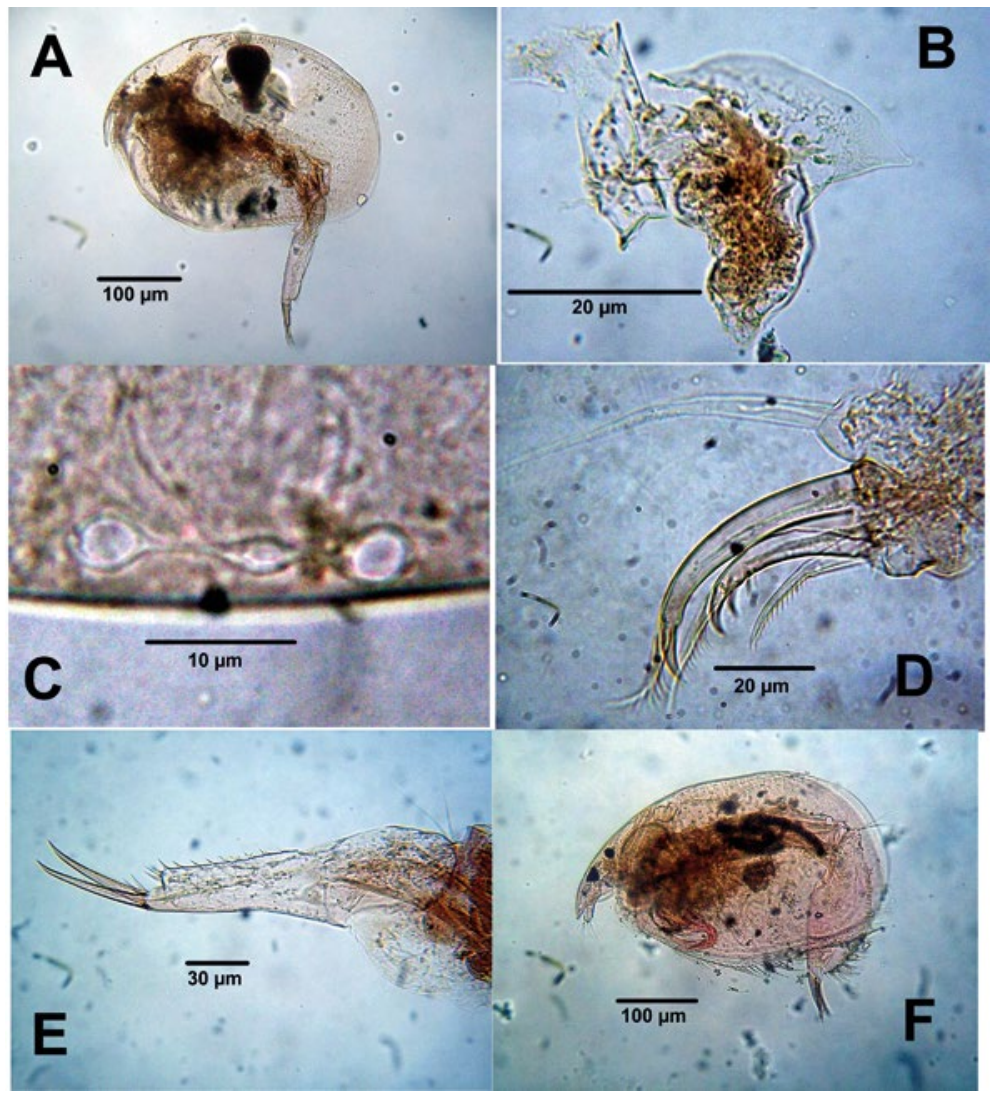

Figure 7. Cladocerans from a temporary pond, La Guajira A-E. Kurzia polyspina. A. Habitus. B. Labrum. C. Head pores. D. Trunk limb I. E. Postabdomen. F. Habitus of male of Leydigia cf. striata. 

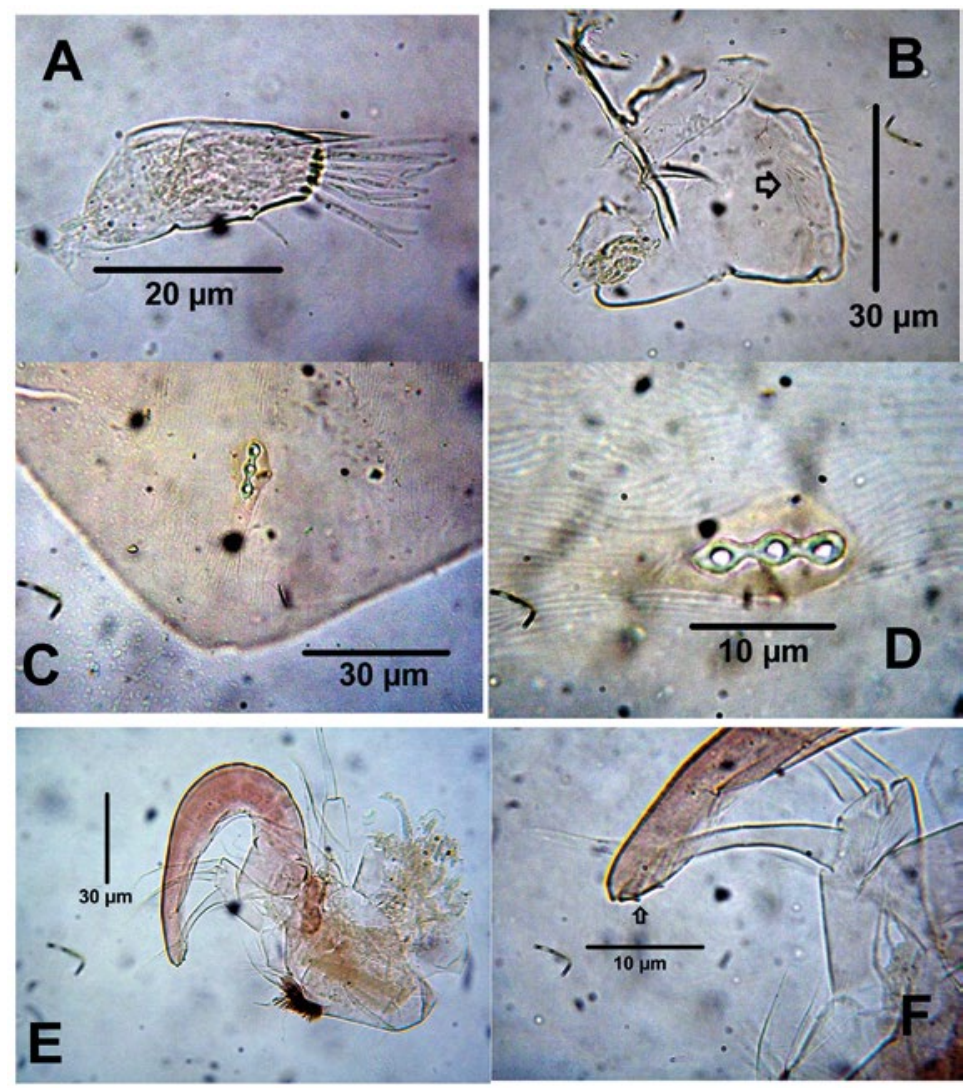

Figure 8. Cladocerans from a temporary pond, La Guajira .Male of Leydigia cf. striata. A. Antenna I. B. Labrum. C. Cephalic shield. D. Head pores. E. Trunk limb I (The arrow points the minute seta). F. Distal end of copulatory hook (The arrow points at minute spines).

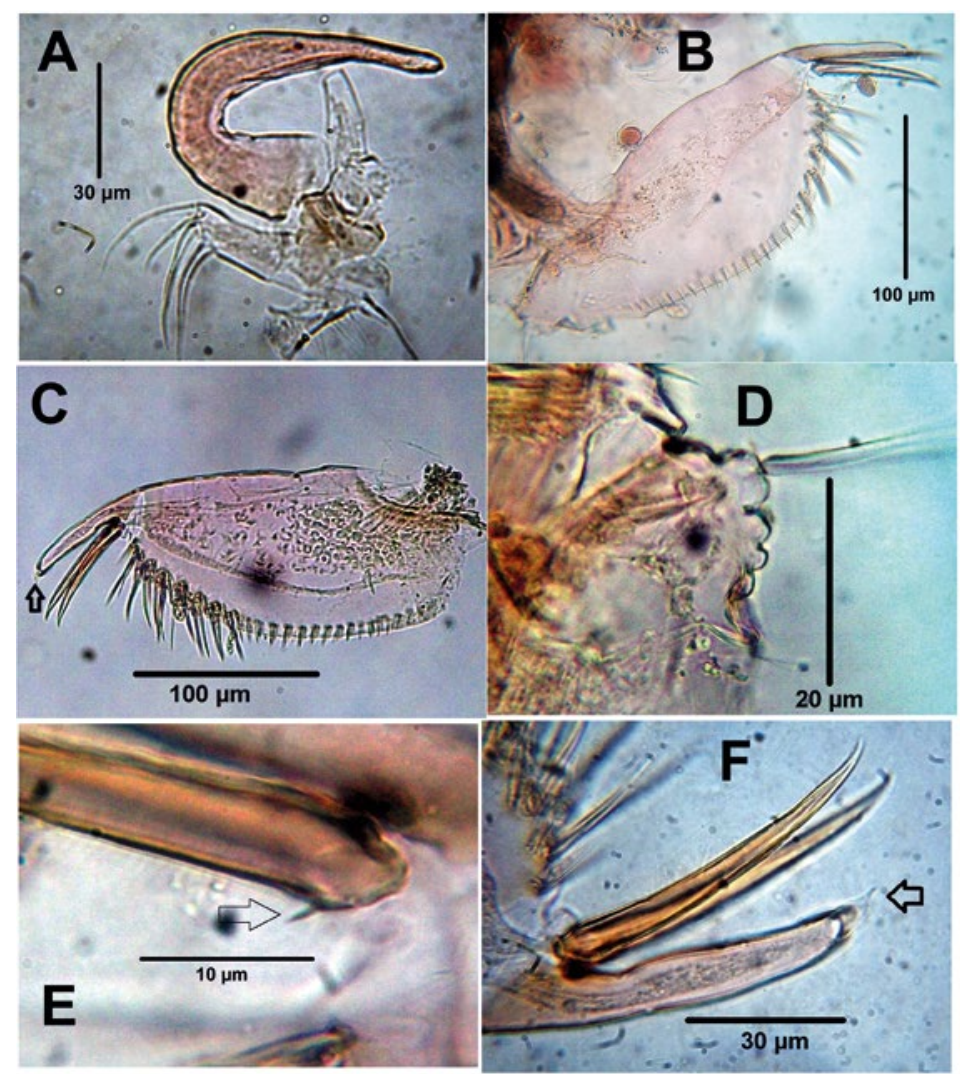

Figure 9. Cladocerans from a temporary pond, La Guajira. Male of Leydigia cf. striata. A. IDL of trunk limb I. B-C. Postabdomen (the arrow points the stylet). D. Preanal margin of postabdomen. E. Basal spine of the claw. F. Penis (The arrow points at the sytlet). 
Remarks: It was found among macrophytes during February. The specimens present the general characteristics of 0 . glabra, such as the habitus (Fig. 10A), three connected head pores (Fig. 10B), oval labrum (Fig. 10C), postabdomen (Fig. 10D), and Limb I (Fig. 10E). Some features observed in the specimens, on the other hand, do not entirely match with Ovalona glabra, suggesting a probable new species. However, the available material was not sufficient for a complete comparison and description of a new taxon of the species rank. Therefore, more specimens should be analyzed. Body length $364-434(n=2)$.

\section{GENUS CHYDORUS LEACH, 1816}

\section{Chydorus nitidulus (Sars, 1901)}

Synonymy: Alonella nitidula Sars, 1901; C. nitidulus, Rey and Vásquez, 1986 in Fuentes-Reinés et al. 2012:152.

Material examined: 2 adult females, catalog number: CBUMAG: MEI: 0033-1, CBUMAG: MEI: 0033-2, CBUMAG: MEI: 0033-3

Remarks: It was originally described as Alonella nitidula by Sars, 1901 and later allocated in the genus Chydorus by Frey 1982a. This species was found among macrophytes during January and has a wide distribution in the northern Colombia (Kotov \& Fuentes-Reinés 2015b). Body length $308-322(\mathrm{n}=2)$.

\section{GENUS DUNHEVEDIA KING, 1853}

\section{Dunhevedia odontoplax Sars, 1901}

Material examined: One adult female, catalog number: CBUMAG: MEI: 0032-1, CBUMAG: MEI: 0032-2

Remarks: It was originally described by Sars (1901). This species, together with D. crassa, was the least abundant among the observed Chydoridae. It was found among macrophytes during January, habitus as in Figure 11A, postabdomen oval and small with many fine spinules on lateral side (Fig. 11B), posterior-ventral of valve with one denticle (Fig. 11C). Its main features is the presence of one denticle on labral plate (Fig. 11D). Body length $434 \mu \mathrm{m}(\mathrm{n}=1)$.

\section{Dunhevedia crassa King, 1853}

Synonymy: Dunhevedia dvihallyana Ponyi, 1955, D. eureticulata Kottász, 1913, D. interrupta Brehm, 1936, D. neglecta Daday, 1903 in Kotov et al. 2013.

Material examined: 1 adult female, catalog number:

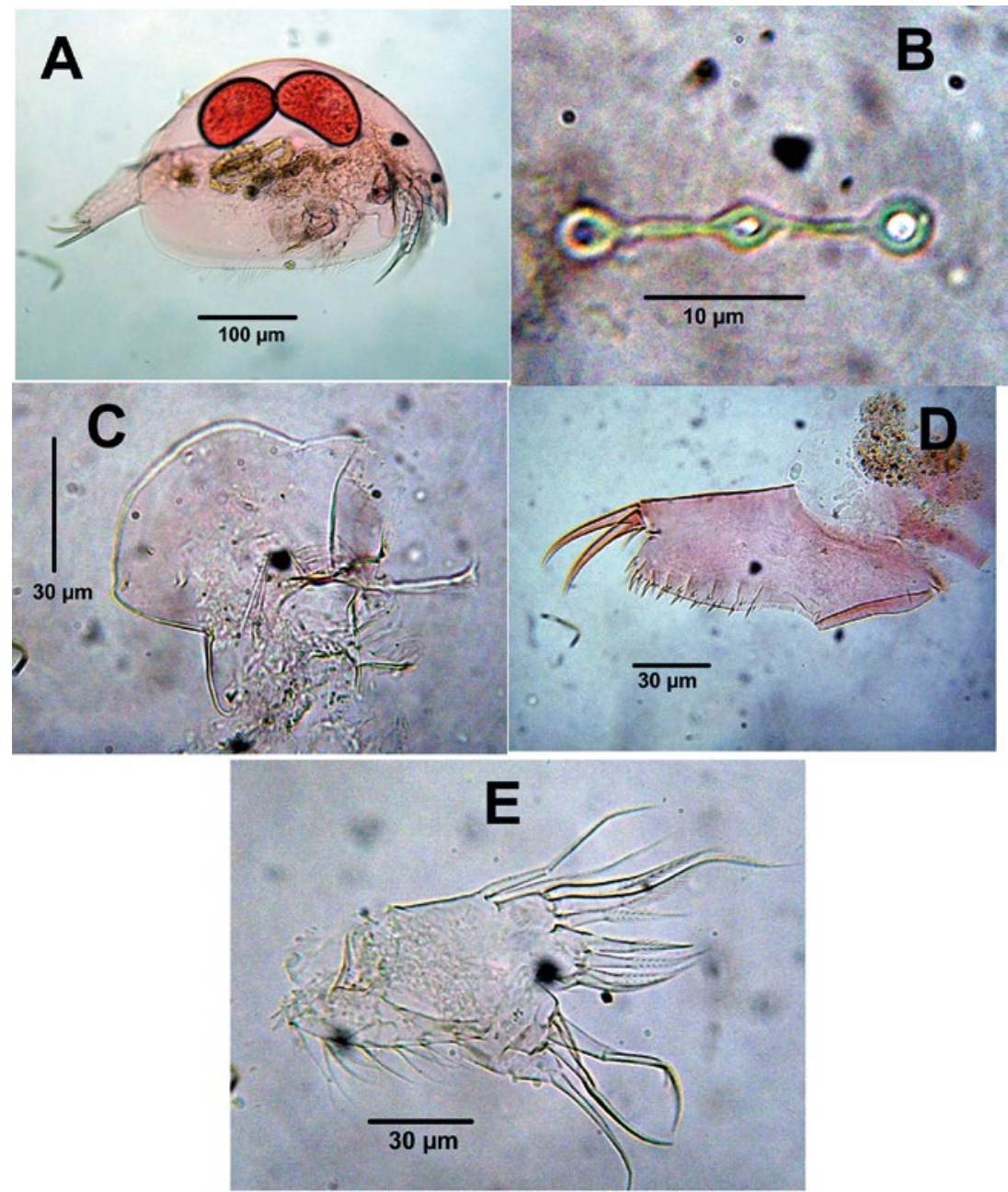

Figure 10. Cladocerans from a temporary pond, La Guajira. Ovalona cf. glabra. A. Habitus. B. Head pores. C. Labrum. D. Postabdomen. E. Trunk limb I. 


\section{CBUMAG: MEI: 0031-1, CBUMAG: MEI: 0031-2}

Remarks: It was originally described from Australia and has a widespread distribution; therefore, following the theory of non-cosmopolitan of species distribution (Frey 1982b, 1991) this taxon should be revised. Dunhevedia crassa was found among macrophyte during February, habitus as in Figure 11E. In Colombia, this species can be confused with D. colombiensis Stingelin, 1913 and $D$. odontoplax, however they can be separated by the labral plate which bear $3-4$ denticles in D. colombiensis (Smirnov, 1996, figs 705-707; Fuentes-Reinés et al. 2012, fig 35 B), one denticle in D. odontoplax (Smirnov 1996, figs 696-697; Fuentes-Reinés et al. 2012, fig 34B), and without denticle or serration in D. crassa (Fig. 11F, Smirnov, 1996, fig 679, Fuentes-Reinés \& Zoppi de Roa 2013, fig $8 \mathrm{~B}$ ), body length $350 \mu \mathrm{m}$.

\section{Discussion}

The cladoceran fauna found in this system of temporary pond contain typical tropical species that have been found in other Colombian system (Fuentes-Reinés et al. 2012, Fuentes-Reinés 2014a, Fuentes-Reinés \& ElmoorLoureiro 2015a), but 12 species represent new records for La Guajira Department (See Table 1).

In recent researches about cladoceran fauna in La Guajira Department, Fuentes-Reinés (2014a, b) reported 18 species in the Laguna Navío Quebrado, thus, the 12 new occurrences in this paper, the total number of species known increase to 30 for La Guajira Department, representing the $40.5 \%$ and $28.03 \%$ of cladoceran fauna in the Caribbean region and Colombian territory respectively. The cladocerans species number in la Guajira Department is still limited taking into account that some common taxa (Alona guttata, Moina minuta, Latonosis australis) can be found in neighboring regions (Magdalena department, Venezuela) and they are yet not reported. We believe that the apparent absence of these species is due to insufficient surveying efforts in the Guajira department.

In the surveyed area, the littoral zone with vegetation showed a higher species richness (11 species) than the limnetic area ( 9 species). The littoral vegetation represents a wide variety of microhabitats for microcrustaceans, providing food and shelter (Choedchim et al. 2017).

In Colombia, records of cladocerans of temporary
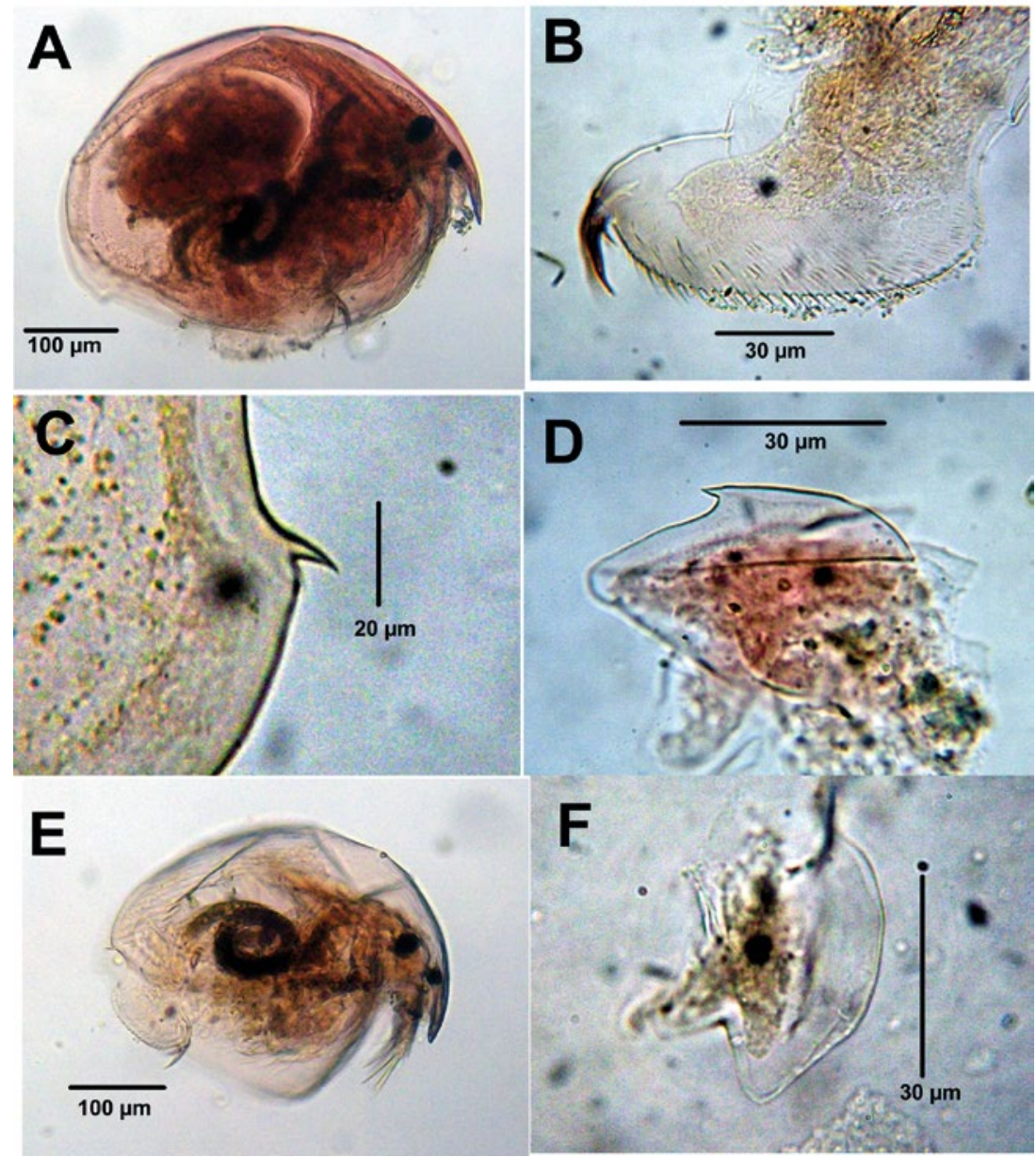

Figure 11. Cladocerans from a temporary pond, La Guajira. A-D. Dunhevedia odontoplax. A. Habitus. B. Postabdomen. C. Posterior-ventral of valve. D. Labrum. E-F. Dunhevedia crassa. E. Habitus. B. Labrum. 
ponds are non-existent, which is probably due to insufficient efforts in cladoceran research, sampling difficulties, and taxonomical problems. This is in contrast with others countries such as Brazil, Argentina, Spain, France, Portugal, South Korea, Chile (Boix et al. 2001, Crispim \& Freitas 2005, Waterkeyn et al. 2008, Caramujo \& Boavida 2010, Vignatti et al. 2012, Diniz et al. 2013, Jeong et al. 2015, Cepeda-Pizarro et al. 2015), where some studies on cladoceran fauna have been carried out in temporary ponds.

The species richness of microcrustacean taxa in this work (18) is high as compared with the results of other researches in temporary ponds. For example, CepedaPizarro et al. (2015) reported two cladoceran species from four temporary ponds in in the Tambo-Puquíos wet pasture (Andes of north-central Chile), Boix et al. (2001) observed five cladocerans species to Northeastern Spain, Crispim and Freitas (2005) in a semi-arid to northeastern Brazil (Paraiba state)and Caramujo and Boavida 2010 in the Natural Park of the Southwest and Vicentina and Coast reported 10 cladoceran species, Waterkeyn et al. (2008) observed 17 cladoceran species from 30 temporary ponds in Southern Frances, Vignatti et al. (2012) recorded three cladoceran species in central region of Argentina (La Pampa province). However, Diniz et al.

Table 1. General distribution of different species of Cladocera in a shallow temporary pond. Geographic category: NT (Neotropical), C (Cosmopolitan), and PAN (Pantropical and pansubtropical). Departments: At (Atlántico), By (Boyacá), Co (Córdoba), Gu (La Guajira) Hu (Huila), To (Tolima), Mg (Magdalena), Sa (Santander). * New records for the La Guajira Department.

\begin{tabular}{|c|c|c|c|c|c|c|}
\hline Family & Taxon & $\begin{array}{l}\frac{1}{ \pm} \\
\stackrel{ \pm}{0} \\
\frac{1}{\Phi} \\
\frac{0}{0}\end{array}$ & 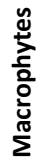 & 은 & 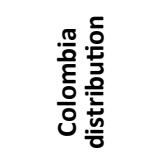 & Reference to Colombia \\
\hline \multirow{5}{*}{ Sididae } & Diaphanosoma brevireme* & $x$ & $x$ & NT & $\begin{array}{l}\text { Sa, Co, Mg, } \\
\text { At, Gu }\end{array}$ & $\begin{array}{l}\text { Barón-Rodríguez et al. 2006, Álvarez 2010, } \\
\text { Fuentes-Reinés et al. 2012, Fuentes-Reinés \& Elmoor-Loureiro } \\
\text { 2015a, present paper. }\end{array}$ \\
\hline & Diaphanosoma spinulosum & $x$ & & NT & $\begin{array}{l}\mathrm{Am}, \mathrm{Co}, \mathrm{Sa} \\
\mathrm{Gu}\end{array}$ & $\begin{array}{l}\text { Barón-Rodríguez et al. 2006, Gallo-Sánchez et al. 2009, Villabo- } \\
\text { na-González et al. 2011, Fuentes-Reinés 2014c. }\end{array}$ \\
\hline & Diaphanosoma dentatum* & $x$ & & NT & Sa & $\begin{array}{l}\text { Barón-Rodríguez et al. 2006, Villabona-González et al. 2011, } \\
\text { present paper. }\end{array}$ \\
\hline & Sarsilotona serricauda* & $x$ & $x$ & NT & $\begin{array}{l}\mathrm{Sa}, \mathrm{Co}, \mathrm{Mg} \\
\mathrm{Gu}\end{array}$ & $\begin{array}{l}\text { Barón-Rodríguez et al. 2006, Álvarez 2010, Fuentes-Reinés et } \\
\text { al. 2012, present paper. }\end{array}$ \\
\hline & Pseudosida* sp. & $x$ & & ---- & $\mathrm{Gu}$ & Present paper. \\
\hline Daphniidae & Ceriodaphnia cornuta & $x$ & & PAN & $\begin{array}{l}\text { At, } \mathrm{Hu}, \mathrm{Co}, \\
\mathrm{Sa}, \\
\mathrm{Mg}, \mathrm{Gu}, \mathrm{To}\end{array}$ & $\begin{array}{l}\text { Camargo-Fajardo 1994, Herrera-Martínez \& Guillot } 1999, \\
\text { Barón-Rodríguez et al. 2006, Guevara et al. 2009, Álvarez 2010, } \\
\text { Fuentes-Reinés et al. 2012, Fuentes-Reinés 2014a, Fuentes- } \\
\text { Reinés \& Elmoor-Loureiro 2015a. }\end{array}$ \\
\hline \multirow{3}{*}{ Moinidae } & Moinodaphnia macleayi & $x$ & & PAN & $\begin{array}{l}\mathrm{Mg}, \mathrm{At}, \mathrm{Sa} \\
\mathrm{Co}, \\
\mathrm{Gu}\end{array}$ & $\begin{array}{l}\text { Pearse 1916, Brehm 1956, Barón-Rodríguez et al. 2006, Álva- } \\
\text { rez 2010, Fuentes-Reinés et al. 2012, Fuentes-Reinés 2014a, } \\
\text { Fuentes-Reinés \& Elmoor-Loureiro 2015a. }\end{array}$ \\
\hline & Moina micrura micrura* & $x$ & & $\mathrm{C}$ & $\begin{array}{l}\text { Sa, Co, By, } \\
\text { Mg, At, Gu. }\end{array}$ & $\begin{array}{l}\text { Barón-Rodríguez et al. 2006, Álvarez 2010, Fuentes-Reinés et } \\
\text { al. 2012, Aranguren-Riaño \& Monroy-González 2014, Fuentes- } \\
\text { Reinés \& Elmoor-Loureiro 2015a, present paper. }\end{array}$ \\
\hline & Moina reticulata* & $x$ & & NT & $\begin{array}{l}\mathrm{Co}, \mathrm{Mg}, \mathrm{At} \\
\mathrm{Gu}\end{array}$ & $\begin{array}{l}\text { Álvarez 2010, Fuentes-Reinés et al. 2012, Fuentes-Reinés } 8 \\
\text { Elmoor-Loureiro 2015, present paper. }\end{array}$ \\
\hline \multirow{3}{*}{ Macrothricidae } & Macrothrix elegans & & $x$ & NT & $\begin{array}{l}\text { Co, } \mathrm{Mg}, \mathrm{Gu} \text {, } \\
\text { At }\end{array}$ & $\begin{array}{l}\text { Álvarez 2010; Fuentes-Reinés et al. 2012, Fuentes-Reinés 2014a. } \\
\text { Fuentes-Reinés \& Elmoor-Loureiro 2015a. }\end{array}$ \\
\hline & Macrothrix spinosa & & $x$ & PAN & $\begin{array}{l}\text { Co, } \mathrm{Mg}, \mathrm{Gu} \text {, } \\
\text { At- }\end{array}$ & $\begin{array}{l}\text { Álvarez 2010; Fuentes-Reinés et al. 2012, Fuentes-Reinés 2014a, } \\
\text { Fuentes-Reinés \& Elmoor-Loureiro 2015a. }\end{array}$ \\
\hline & Grimaldina freyi* & & $x$ & NT & $\mathrm{Mg}, \mathrm{Sa}, \mathrm{Gu}$ & $\begin{array}{l}\text { Barón-Rodríguez et al. 2006, Fuentes-Reinés et al. 2012, pre- } \\
\text { sent paper. }\end{array}$ \\
\hline \multirow{6}{*}{ Chydoridae } & Kurzia polyspina* & & $x$ & NT & $\mathrm{Mg}, \mathrm{Gu}$ & Fuentes-Reinés et al. 2012, present paper. \\
\hline & Leydigia cf striata* & & $x$ & NT & $\mathrm{Sa}, \mathrm{At}, \mathrm{Gu}$ & $\begin{array}{l}\text { Barón-Rodríguez et al. 2006; Fuentes-Reinés 2014b, Fuentes- } \\
\text { Reinés \& Elmoor-Loureiro 2015a, present paper. }\end{array}$ \\
\hline & Ovalona cf glabra* & & $x$ & NT & $\mathrm{Mg}, \mathrm{Gu}$ & Fuentes-Reinés et al. 2012, present paper. \\
\hline & Chydorus nitidulus* & & $x$ & NT & Co, Mg, Gu & Álvarez 2010, Fuentes-Reinés et al. 2012, present paper. \\
\hline & Dunhevedia odontoplax & & $\mathrm{x}$ & NT & $\mathrm{Cu}, \mathrm{Mg}, \mathrm{Gu}$ & Stingelin 1913, Fuentes-Reinés et al. 2012, Fuentes-Reinés 2014a. \\
\hline & Dunhevedia crassa* & & $x$ & NE & $\mathrm{Mg}, \mathrm{Gu}$ & Fuentes-Reinés \& Zoppi de Roa, 2013, present paper. \\
\hline
\end{tabular}


(2013) in Caatinga of Pernambuco (Brazil), and Jeong et al. (2015) in South of Korea, in their studies about cladoceran fauna, found a higher species richness (22 and 26 species respectively) than our studies. The richness of species in temporary ponds depend on: (1) heterogeneity and the varied network of habitats they provide, (2) hydroperiod, (3) the size and depth of the pond, (4) sampling method (Boix et al. 2001, Razgour et al. 2010)

Studies about cladoceran fauna in temporary ponds in Colombia have been neglected and, therefore, we expect that this manuscript will motivate an increase in this kind of studies, supported by a robust taxonomic base, leading to new records and, consequently, to a better comprehension of the Colombian diversity of freshwater microcrustaceans.

\section{Literature cited}

Álvarez, J. 2010. Caracterización de las ciénagas de Arcial, Porro y Cintura (río San Jorge) y de Bañó Charco Pescao y Pantano Bonito (Río Sinú), departamento de Córdoba. In: J.O. Rangel, Eds Colombia, diversidad biótica IX, Ciénaga de Córdoba: Biodiversidad, ecología y manejo ambiental. Universidad Nacional de Colombia, Bogotá. Pp.509-558.

Aranguren-Riaño N.J. \& J.D. Moroy-González. 2014. Respuestas del zooplancton en un sistema tropical (embalse la chapa, Colombia) con alta tensión ambiental. Acta Biológica Colombiana 19 (2), 281-290. doi: http:// dx.doi.org/10.15446/abc.v19n2.38095

Barón-Rodríguez M., R. Gavilán \& J.J. Ramírez. 2006. Variabilidad espacial y temporal en la comunidad de cladóceros de la Ciénaga de Paredes (Santander, Colombia) a lo largo de un ciclo anual. Limnética. 25(3): 624-635.

Boix D., J. Sala \& R. Moreno-Amich, 2001. The faunal composition of Espolla Pond (NE Iberian Peninsula): The neglected biodiversity of temporary waters. Wetlands. 21(4): 577-592. doi: https://doi.org/10.1672/02775212(2001)021[0577:TFCOEP]2.0.C0;2

Brehm V. 1956. Cladocera aus Venezuela. In F. Gessner \& V. Vareschi (eds.), Ergebnisse der deutschen limnologischen Venezuela-Expedition 1952. Deutscher Verlag Wissenschaften, Berlin: 217-232.

Camargo F. 1994. Estudio cualitativo y semicuantitativo del zooplancton superficial en el Embalse El Guájaro (Atlántico), Colombia. Trianea. 5: 235-253

Caramujo M.J. \& M.J. Boavida. 2010. Biological diversity of copepods and cladocerans in Mediterranean temporary ponds under periods of contrasting rainfall. Journal of limnology 69(1): 64-75. doi: http://dx.doi. org10.3274/JL10-69-1-06

Cepeda-Pizarro J., Pizarro-Araya J. \& M.C. Morales. 2015. Invertebrates inhabiting temporary ponds found in the Tambo-Puquíos wet pasture (Andes of north-central Chile), and the physicochemical characteristics of their habitat. IDESIA (Chile), 33(4):55-64. doi: http:// dx.doi.org/10.4067/S0718-34292015000400008

Crispim M.C. \& G.T. Freitas. 2005. Seasonal effects on zooplanktonic community in a temporary lagoon of northeast Brazil. Acta Limnologica Brasiliensia 17(4): 385-393.

Choedchim W., K. Van Damme \& S. Maiphae. 2017. Spatial and temporal variation of Cladocera in a tropical shallow lake. Annales de Limnologie - International Journal of Limnology 53:233-252. doi: http://dx.doi. org10.1051/limn/2017006
Daday E von, W. Michaelsen. 1905. Untersuchungen über die Süsswasser-Mikrofauna Paraguays. Zoologica (E. Schweizerbart'sche Verlagsbuchhandlung), Heft 44. Stuttgart, E. Nägele. pp 1-374. doi: https://www.biodiversitylibrary.org/item/43149.

Diniz L.P., L.M.A. Elmoor-Loureiro, V.L.S. Almeida \& M. MeloJunior. 2013. Cladocera (Crustacea, Branchiopoda) of a temporary shallow pond in the Caatinga of Pernambuco, Brazil. Nauplius. 21, 65-78. doi: http://dx.doi. org/10.1590/S0104-64972013000100008

Elías-Gutiérrez M., A. Kotov \& T. Garfías-Espejo. 2006. Cladocera (Crustacea: Ctenopoda, Anomopoda) from southern Mexico, Belize and northern Guatemala, with some biogeographical notes. Zootaxa. 1119: 1-27. doi: http://dx.doi.org/10.11646/zootaxa.1119.1.1

Elías-Gutiérrez M., P.J. Juračka, L. Montoliu-Elena, M.R. Miracle, A. Petrusek, V. Koř́nek, 2019. Who is Moina micrura? Redescription of one of the most confusing cladocerans from terra typica, based on integrative taxonomy. Limnetica. 38(1): 227-252. doi:: http://dx.doi. org10.23818/limn.38.18

Elías-Gutiérrez M., E. Suárez, M. Gutiérrez, M. Silva, J. Granados \& T. Garfia. 2008. Cladócera y Copépoda de las aguas continentales de México. UNAM, México D.F. 323 pp.

Elmoor-Loureiro L.M.A. 1997. Manual de identificação de cladóceros límnicos do Brasil. Universida de Católica de Brasília, Editora Universa, Brasilia. 156 pp.

Frey D.G. 1982a. Relocation of Chydorus barroisi and related species (Cladocera, Chydoridae) to a new genus and description of two new species. Hydrobiologia. 86: 231-269. doi: https://doi.org/10.1007/BF00006141

Frey D.G. 1982b. Questions concerning cosmopolitanism in Cladocera. Archiv für Hydrobiologie 93, 484-502.

Frey D.G. 1991. A new genus of Alonine chydorid cladocerans from athalassic saline waters of New South Wales, Australia. Hydrobiologia, 224, 11-48. doi: http:// dx.doi.org/10.1007/BF00006361

Fuentes-Reinés J.M. 2014a. New Records of Cladocera (Crustacea: Anomopoda) from Laguna Navío Quebrado, La Guajira Department, Colombia. Nauplius. 22 (2), 21-32. doi: http://dx.doi.org/10.1590/S010464972014000100003

Fuentes-Reinés J.M. 2014b. Leydigia (Neoleydigia) cf. striata Birabén, 1939 (Crustacea: Cladocera: Chydoridae) from Colombia and its differentiation from L. (N.) cf. ipojucae (Brehm, 1938). Nauplius. 22 (2), 67-73. doi: http:// dx.doi.org/10.1590/S0104-64972014000200001

Fuentes-Reinés J.M. 2014c. Presence of Diaphanosoma spinulosum Herbst, 1975 (Crustacea: Cladocera: Ctenopoda, Sididae) in a coastal system of northern Colombia, with comments on D. birgei Kořínek, 1981. Boletín de Investigaciones Marinas y Costeras - INVEMAR 43 (2), 407-413. doi: https://doi.org/10.25268/bimc.invemar.2014.43.2.35

Fuentes-Reinés J.M. 2015. First record of Parvalona parva (Daday, 1905) (Crustacea: Anomopoda: Chydoridae) from Colombia. Check List. 11(4): 1-5. doi: http://dx.doi. org $/ 10.15560 / 11.4 .1691$

Fuentes-Reinés J.M. \& L.M.A. Elmoor-Loureiro. 2015a. Annotated checklist and new records of Cladocera from the Ciénaga El Convento, Atlántico-Colombia. PanAmerican Journal of Aquatic Sciences 10(3):189202. doi: https://panamjas.org/pdf_artigos/PANAMJAS_10(3)_189-202.pdf 
Fuentes-Reinés J.M. \& L.M.A. Elmoor-Loureiro. 2015b. First record of Karualona penuelasi (Cladocera: Anomopoda: Chydoridae) from Colombia. Revista mexicana de biodiversidad 86 (2015) 1091-1094. doi: http://dx.doi. org/10.1016/j.rmb.2015.06.015

Fuentes-Reinés J.M. \& L.M.A. Elmoor-Loureiro. 2011 Occurrence of Guernella raphaelis Richard, 1892 (Crustacea: Cladocera: Macrothricidae) in Ciénaga Grande de Santa Marta, Colombia. Check List. 7, 817-819 doi: http://dx.doi.org/10.15560/11042

Fuentes-Reinés J.M \& E. Zoppi de Roa. 2013 New additions to the cladoceran fauna of Ciénaga Grande de Santa Marta and Colombia. Check List. 9, 9-24. doi: https://doi. org/10.15560/9.1.9

Fuentes-Reinés J.M., L.M.A. Elmoor-Loureiro \& C.E. GranadosMartínez. 2018. New records of Cladocera (Crustacea: Branchiopoda) from the Tomo River, Vichada, Colombia. Nauplius. 26 (e2018006): 1-12, doi: http://dx.doi. org/10.1590/2358-2936e2018006

Fuentes-Reinés J.M., E. Zoppi de Roa, E. Morón, D. Gámez \& C. López. 2012. Conocimiento de la fauna de Cladocera (Crustacea: Branchiopoda) de la Ciénaga Grande de Santa Marta, Colombia. Boletín de Investigaciones Marinas y Costeras - INVEMAR 41, 121-164. doi: http:// dx.doi.org/10.25268/bimc.invemar.2012.41.1.76

Gallo-Sánchez L., N. Aguirre, J. Palacio \& J. Ramírez. 2009. Zooplancton (Rotífera y Microcrustacea) y su relación con los cambios del nivel del agua en la ciénaga de Ayapel, Córdoba, Colombia. Caldasia. 31 (2): 339-353. doi: http://dx.doi.org/10.15446/caldasia

Guevara G., P. Lozano, G. Reinoso \& F. Villa. 2009. Horizontal and seasonal patterns of tropical zooplankton from the eutrophic Prado Reservoir (Colombia). Limnologica. 39: 128-139.

Harding J.P. 1955. The Percy Sladen Trust Expedition to Lake Titicaca in 1937 XIX. Crustacea: Cladocera. Transactions of the Linnean Society of London (3)1:329-354.

Hudec I. 2000. Subgeneric differentiation within Kurzia (Crustacea: Anomopoda: Chydoridae) and a new species from Central America. Hydrobiologia, 421: 165-178. doi: https://doi.org/10.1023/A:1003919712255

Herrera-Martínez, Y. \& G. Guillot. 1999. Composición taxonómica del zooplancton del Embalse de Betania, departamento del Huila. Acta Biológica Colombiana 4(1): 5-21.

Kořínek V. 1984. Cladocera. Hydrobiological Survey of Lake Bangweulu and Luapulu River Basin. Journal of Symoens Cercle Hydrobiologique de Bruxelles. 13 (2), 1-117.

Korovchinsky N. M. 1992. Sididae and Holopedidae. SPB Academic Publishing, Amsterdam. 82 pp.

Kotov A.A. 2009. A revision of Leydigia Kurz, 1875 (Anomopoda, Cladocera, Branchiopoda), and subgeneric differentiation within the genus. Zootaxa. 2082, 1-68. doi: http://dx.doi.org/10.11646/zootaxa.2082.1.1

Kotov A.A. \& M. Elías-Gutiérrez. 2004. Notes on Aloninae Dybowski and Grochowski, 1894, emend. Frey 1987. (Cladocera: Anomopoda: Chydoridae): 2 Leydigia cf striata Birabeén 1939 in South Mexico. Arthropoda Selecta 13(1-2):1-16.

Kotov A.A. \& J.M. Fuentes-Reinés. 2014. A new species of Leydigia Kurz, 1875 (Cladocera: Chydoridae) from Colombia. Zootaxa, 3814 (3), 399-408. doi: http://dx.doi. org/10.11646/zootaxa.3814.3.7
Kotov A.A. \& J.M. Fuentes-Reinés, 2015a. A new species of Leberis Smirnov, 1989 (Cladocera: Chydoridae) from Colombia. Zootaxa, 3957 (5), 553-566. doi: http:// dx.doi.org/10.11646/zootaxa.3957.5.4

Kotov A.A. \& J.M. Fuentes-Reinés. 2015b. An annotated checklist of the Cladocera (Crustacea: Branchiopoda) of Colombia. Zootaxa 4044 (4): 493-510. doi: http:// dx.doi.org/10.11646/zootaxa.4044.4.2

Kotov A.A., T. Garfias-Espejo, \& M. Elías-Gutiérrez. 2004. Separation of two Neotropical species: Macrothrix superaculeata (Smirnov, 1982) versus M. elegans Sars, 1901 (Macrothricidae, Anomopoda, Cladocera). Hydrobiologia. 517: 61-88, 2004. doi: https://doi. org/10.1023/B:HYDR.0000027337.57305.b0

Kotov A. A., K. Van Damme, \& M. Elías-Gutiérrez. 2003. Differentiation between African Leydigia ciliata Gauthier, 1939 and Neotropical L. cf. striata Birabén, 1939 (Chydoridae, Anomopoda, Cladocera). Hydrobiologia. 505,179-197. doi: https://doi.org/10.1023/ B:HYDR.0000007246.04478.6a

Lamoot E. \& H.J. Dumont. 1974 Moina reticulata (Daday, 1905) (Cladocera, Moinidae) found in the Ivory Coast, West Africa. Crustaceana, 26, 29-32. doi: http://dx.doi. org/10.1163/156854074X00037

Melão M.G.G., O. Rocha \& K.F. Roche. 2005. Produtividade, biomassa, flutuações populacionais e interações biológicas dacomunidade planctônica e suas implicações na transferência de energia na cadeia alimenta de um reservatório raso e oligotrófico. In: K.F. Roche \& 0. Rocha, eds, Ecologia Trófica de Peixes com ênfase na planctivoria em ambientes lênticos de agua doce no Brasil. Rima, São Carlos. Pp. 25-80,

Neretina A.N. \& A. Kotov. 2017. Old World-New World differentiation of so-called "circumtropical" taxa: the case of rare genus Grimaldina Richard, 1892 (Branchiopoda: Cladocera: Macrothricidae). Zootaxa. 4291 (2): 295323 doi: https://doi.org/10.11646/zootaxa.4291.2.4

Pearse A.S. 1916. An account of the Crustacea collected by the Walker Expedition to Santa Marta Colombia. Proceedings of the United States National Museum 49(2123): 530-556. doi: https://doi.org/10.5479/ si.00963801.49-2123.531

Razgour O., C. Korine \& D. Saltz. 2010. Pond characteristics as determinants of species diversity and community composition in desert bats. Animal Conservation. 13 (2010) 505-513. doi: https://doi.org10.1111/j.14691795.2010.00371.x

Sars G.O. 1885. On some Australian Cladocera, raised from dried mud, Norske. Vidensk, Selsk, Forhandt. Christiania. 8: 1-46.

Sars G.O. 1901. Contributions to the knowledge of the fresh-water Entomostraca of South America, as shown by artificial hatching from dried material. 1. Cladocera. Archiv for Mathematik og Naturvidenskab. 23 (3), 1-102

Sharma P. \& A.A. Kotov. 2013. Molecular approach to identify sibling species of the Ceriodaphnia cornuta complex (Cladocera:Daphniidae) from Australia with notes on the continental endemism of this group. Zootaxa. 3702 (1): 79-89. doi: http://dx.doi.org/10.11646/ zootaxa.3702.1.5

Sinev A.Y. \& J.M. Fuentes-Reinés. 2016. A new subspecies of Ovalona setulosa (Megard, 1967) (Cladocera: Anomopoda:Chydoridae) from the Caribbean coast of Colombia. Zootaxa. 4121: 49-58. doi: https://doi. org/10.11646/zootaxa.4121.1.2 
Smirnov. N.N. 1996. Cladocera: the Chydorinae and Sayciinae (Chydoridae) of the world. Guides to the identication of the microinvertebrates of the continental waters of the world. Vol. 11. Amsterda. The Hague, SPB Academic Publishing, 197p.

Sousa F.D.R. \& L.M.A. Elmoor-Loureiro. 2008. Cladóceros fitófilos (Crustacea, Branchiopoda) do Parque Nacional das Emas, estado de Goiás. Biota Neotropica 8(1):159-166. doi: http://dx.doi.org/10.1590/S167606032008000100019

Stingelin T. 1913. Cladoceren aus den Gebirgen von Kolumbien. Mem. Soc. Neuchateloise. Memoires de la Société Neuchâteloise des Sciences Naturelles 5: 600-638

Vignatti A.G. Cabrera \& S. Echaniz. 2012. Changes in the zooplankton and limnological variables of a temporary hypo-mesosaline wetland of the central region of Argentina during its drying. Pan-American Journal of Aquatic Sciences. 7(2): 93-106.

Villabona-González, S.L., N.J. Aguirre \& A.L. Estrada. 2011. Influencia de las macrófitas sobre la estructura poblacional de rotíferos y microcrustáceos en un plano de inundación tropical. Revista de Biología Tropical 59 (2), 853-870. doi: https://doi.org/10.15517/rbt. v0i0.3145

Waterkeyn A., P. Grillas, B. Vanschoenwinkel \& L. Brendonck. 2008. Invertebrate community patterns in Mediterranean temporary wetlands along hydroperiod and salinity gradients. Freshwater Biology 53: 1808-1822. doi: https://doi.org/10.1111/j.1365-2427.2008.02005.x

\section{Agradecimientos:}

We want to thank to Dr. Alexei Kotov (A. N. Severtsov Institute of Ecology and Evolution, Leninsky Prospect 33, Moscow 119071, Russia) for kindly providing useful taxonomic literature during the development of this work. We also are indebted to the student Jorge Olivero for his valuable help in the field.

Rol de los autores:

JFR and PEE collected the samples; JFR and LMAEL identified the specimens; JFR, PEE and LMAEL wrote the text.

Conflicto de intereses:

The authors declare that they have no conflict of interest.

Fuentes de financiamiento:

The Grupo de investigación en Biodiversidad y Ecología received total support through the Universidad del Magdalena, Vicerrectoria de investigación, Fonciencia 2017.

Aspectos éticos / legales:

Autoridad Nacional de Licencias Ambientales (ANLA). Collection permit No: 1293 . 